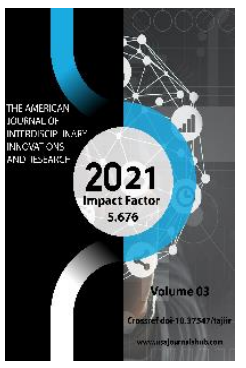

Journal Website: https://theamericanjou rnals.com/index.php/ta jiir

Copyright: Original content from this work may be used under the terms of the creative commons attributes 4.0 licence.

\section{Ways To Establish A Trade Cluster And Improve Its Efficiency}

\author{
Qarshibaevich Pardaev Mamayunus \\ Professor, Doctor Of Economics, Samarkand Institute Of Economics And Service Tashkent, \\ Uzbekistan
}

\section{Umidjon Normurad Ugli Normuradov}

Head Of The Department Of Economic Theory, Samarkand Institute Of Economics And Service, Uzbekistan

\title{
ABSTRACT
}

The article discusses issues related to the organization of a trade cluster and improving the evaluation of its effectiveness. At the same time, some ideas related to the organization of trade clusters in Samarkand region and the assessment of their effectiveness are presented using practical data. A model of the interdependence of the entities included in the trade cluster has been developed, and the role and function of each in the cluster is also covered.

\section{KEYWORDS}

Trade, Cluster, Trade Cluster, Material Wealth, Commodity, Intangible Wealth, Financial Resource, Cash, Trading Process, Ownership Rights.

\section{INTRODUCTION}

Trade has always played an important role in human life. Because the basic needs of people are met through this service. The one who grows his goods and products needs to sell it, and the consumer needs to get it. The role and place of trade is also great in addressing this bilateral need. In any case, trade is booming. Despite the continuation of the pandemic, in
2020 the volume of retail trade turnover in Samarkand region increased by $107.3 \%$. This figure indicates the high growth rate of trade in all regions of the country. This indicates the competitiveness of the trade sector in the region. To further strengthen this, it will be possible to organize trade clusters and use their innovative potential. 


\section{THE MAIN RESULTS AND FINDINGS}

In order to analyze the process of formation of a regional trade cluster in Samarkand region, we used the "integral localization coefficient". Today, in research in the field of "regional economy", "regional economy", "economic geography", as well as in scientific works created in this area, the authors use the localization coefficient to determine the degree of specialization of a region in a particular industry. In our opinion, this indicator can be used to determine the level of trade specialization of the region, as well as the possibility of forming a regional trade cluster. In determining the level of specialization of trade in Samarkand region, we developed the following proposal: using key indicators (luz; Isam) reflecting the development of trade infrastructure at the national and regional levels, trade development coefficients were determined separately for national and regional levels (Kuz; Ksam) conclusions are given.

We have witnessed that the evaluation system in the field of trade can be used directly by the method developed by D.H Aslanova and M.T .Alimova. This is done as follows':

1. If the indicator determined at the regional level (Ii(sam)); sequence number of $\mathrm{i}$ indicators) is greater than the indicator determined at the national level (li(uz)); sequence number of i-indicators), respectively, the localization coefficient for the region is $\mathbf{K i}(\mathbf{s a m})=2$, at the national level, this figure is assumed to be $\mathbf{K ~} \mathbf{i}(\mathbf{u z})=$ o.

\footnotetext{
${ }^{1}$ AslanovaD.X., AlimovaM.T. Opportunities for the formation of a regional tourism cluster in Samarkand region. Scientific electronic journal
}

2. If the indicator determined at the regional level (li(sam)) is equal to the indicator determined at the national level (li(uz)), respectively, the localization coefficient for the region is $\mathbf{K i}(\mathbf{s a m})=1$, and at the national level this figure is $\mathbf{K} \mathbf{i}(\mathbf{u z})=1$ assumed to be equal;

3. If the indicator determined at the regional level (Ii(sam)) is smaller than the indicator determined at the national level (li(uz)), then the localization coefficient for the region is $\mathbf{K i}(\mathbf{s a m}=0$, and at the national level this indicator is $\mathbf{K} \mathbf{i}(\mathbf{u z})=2$. assumed to be equal;The regional localization coefficient (Ksam) is calculated as follows:

4. $\mathrm{Ksam}=\sum_{i=0}^{n} \mathrm{Ki}(\mathrm{sam})$;

Herein:

$\mathrm{i}$-the serial number of the indicators included in the analysis;

$\mathrm{n}$ - the number of indicators included in the analysis;

$\mathrm{K}_{\mathrm{i}}(\mathrm{sam})$-the coefficient of integral localization by region.

It is recommended that this indicator be determined at the national level as follows:

$$
\kappa u z=\sum_{i=0}^{n} \kappa i(\mathrm{uz}) ;
$$

Where: Ki (uz) is the coefficient of integral localization at the country level.

If $\mathbf{K}_{\mathrm{sam}}>\mathbf{K}_{\mathrm{uz}}>$, the conclusion that there is a process of formation of a trade cluster in Samarkand region is confirmed. The analysis

"Economy and Innovative Technologies". № 4, JulyAugust, 2016. 
uses indices and localization coefficients to determine the level of trade specialization in the country and region by 2020 , based on the data of the Statistics Committee of the Republic of Uzbekistan, using a set of indicators that allow to assess the level of development of trade in the region and the country. We recommend the following table to identify and calculate these indicators (Table 1).

Table 1

Set of indicators used in the analysis (in 2020)

\begin{tabular}{|c|c|c|c|}
\hline № & Name of indicators & $\begin{array}{l}\text { In the Republic } \\
\text { of Uzbekistan }\end{array}$ & $\begin{array}{l}\text { In the } \\
\text { Samarkand } \\
\text { region }\end{array}$ \\
\hline$K_{1}$ & Share of trade services in GDP and GDP, in \% & 9,7 & 9,9 \\
\hline $\mathbf{K}_{\mathbf{2}}$ & $\begin{array}{l}\text { The share of trade services in total services created at the } \\
\text { national and regional levels, in } \%\end{array}$ & 25,8 & 29,3 \\
\hline $\mathbf{K}_{3}$ & $\begin{array}{l}\text { The share of the population engaged in trade in the total } \\
\text { employment structure at the national and regional levels, } \\
\text { in\% }\end{array}$ & 10,3 & 10,6 \\
\hline $\mathbf{K}_{4}$ & $\begin{array}{l}\text { The share of trade organizations in the total number of } \\
\text { organizations registered in the country and region, in\% }\end{array}$ & 27,8 & 28,9 \\
\hline $\mathbf{K}_{5}$ & $\begin{array}{l}\text { Number of trade enterprises per 10,000 population of the } \\
\text { country and the region. }\end{array}$ & 43 & 41 \\
\hline $\mathbf{K}_{6}$ & $\begin{array}{c}\text { Sales area of shops per } 10,000 \text { inhabitants of the country } \\
\text { and the region, thousandm }{ }^{2}\end{array}$ & 1,7 & 2,0 \\
\hline
\end{tabular}

Based on the data presented in this table, we can see that in all respects, Samarkand region is higher than such indicators of the country. Only the number of trade enterprises per 10,000 inhabitants of the country and the region (Samarkand region) is less than 2. Using the above methods, it is possible to make a comparative analysis of the indexes of the level of specialization in the field of trade of the Republic of Uzbekistan and Samarkand region and the coefficients of regional localization. To do this, we recommend creating the following table (Table 2). 
Table 2.

Comparative analysis of trade specialization indices and regional localization coefficients of the Republic of Uzbekistan and Samarkand region

\begin{tabular}{|c|c|c|c|c|c|c|}
\hline Index & $\begin{array}{l}\text { The } \\
\text { Republic } \\
\text { of } \\
\text { Uzbekistan }\end{array}$ & $\begin{array}{c}\text { Samarkand } \\
\text { district }\end{array}$ & coefficients & $\begin{array}{l}\text { The } \\
\text { Republic of } \\
\text { Uzbekistan }\end{array}$ & \multicolumn{2}{|c|}{$\begin{array}{l}\text { Samarkand } \\
\text { region }\end{array}$} \\
\hline 1 & 2 & 3 & 4 & 5 & \multicolumn{2}{|c|}{6} \\
\hline$I_{1}$ & 9,7 & 9,9 & $\mathbf{K}_{1}$ & 0 & \multicolumn{2}{|c|}{2} \\
\hline$I_{2}$ & 25,8 & 29,3 & $\mathbf{K}_{2}$ & 0 & \multicolumn{2}{|c|}{2} \\
\hline $\mathrm{I}_{3}$ & 10,3 & 10,6 & $\mathbf{K}_{3}$ & 0 & \multicolumn{2}{|c|}{2} \\
\hline $\mathrm{I}_{4}$ & 27,8 & 28,9 & $\mathbf{K}_{4}$ & 0 & \multicolumn{2}{|c|}{2} \\
\hline $\mathrm{I}_{5}$ & 43 & 41 & $\mathrm{~K}_{5}$ & 2 & \multicolumn{2}{|c|}{0} \\
\hline$I_{6}$ & 1,7 & 2,0 & \multicolumn{2}{|c|}{$\mathbf{K}_{6}$} & 0 & 2 \\
\hline$\Sigma$ & 118,3 & 121,7 & \multicolumn{2}{|c|}{$\Sigma$} & 2 & 10 \\
\hline
\end{tabular}

According to the analysis of this table, the coefficient of integral localization in Samarkand region is $\mathrm{K}$ (sam) $=10$ (optimal value: $\mathrm{K}(\mathrm{sam})$ optimal $=12$ ), indicating the high level of specialization in trade in Samarkand 4 region, the relative location of trade enterprises in the geographical area. , confirms the process of formation of the regional trade cluster. The graphical representation of "Integral Localization Indicators" illustrates this situation even more clearly (Figure 1). 
Figure 3.

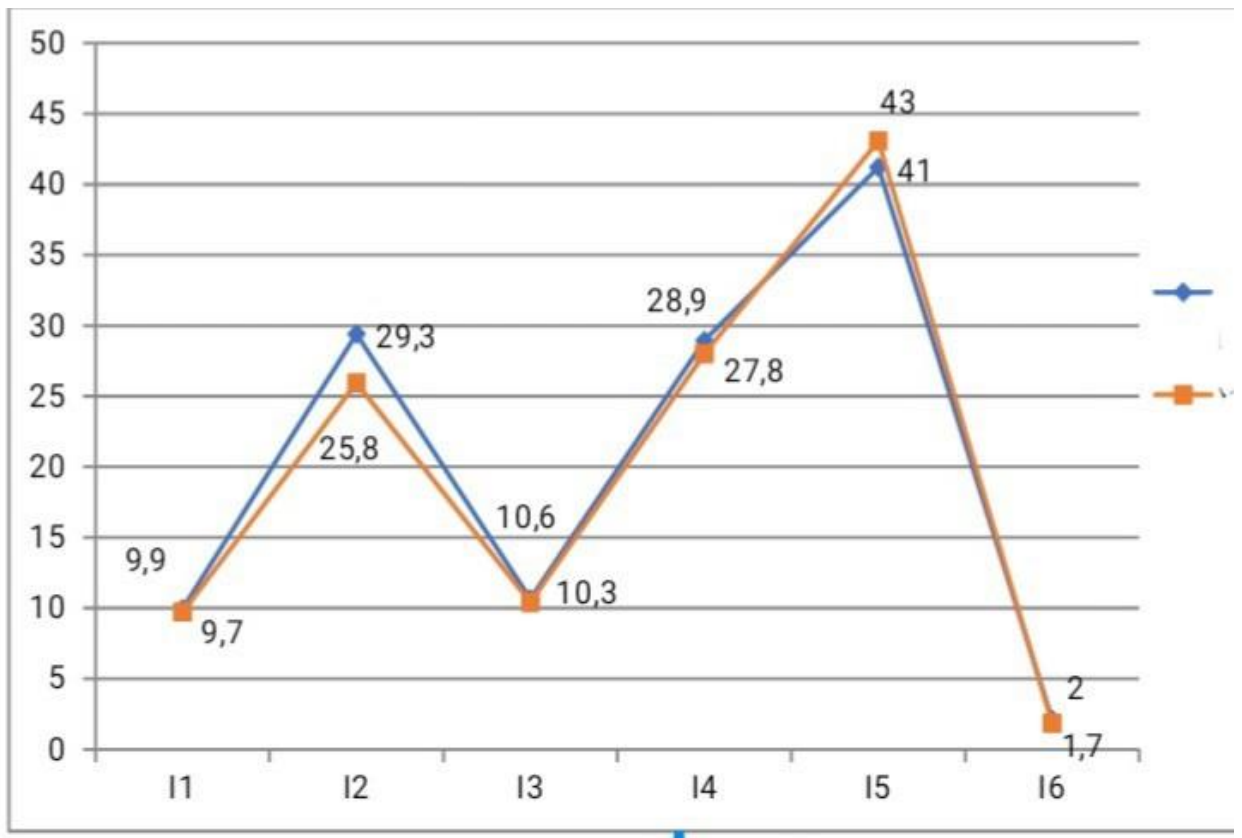

According to the analysis, the level of development of trade in Samarkand region is higher than in the country. Coefficients $\mathbf{I}_{1}, \mathbf{I}_{2}, \mathbf{I}_{3}$ used in the analysis show that the share of trade in the regional economy is higher than the corresponding indicators of the economy of our country and some other regions. The high value of 14 at the regional level indicates the adequate development of trade infrastructure in the region, which is a key element of the trade sector - one of the factors creating favorable conditions for the formation and development of trade enterprises and regional trade cluster. In addition, the integral localization coefficient was calculated for the entire region based on statistical data. However, if the boundaries of the region were reduced and calculated for individual regions with a high degree of specialization in trade (for example, in the city of Samarkand), the localization coefficient would have adopted an optimal value. This situation can be a full basis for the formation and development of a regional trade cluster in Samarkand region. Based on the above data, we found it expedient to form a trade cluster (Figure 2). 


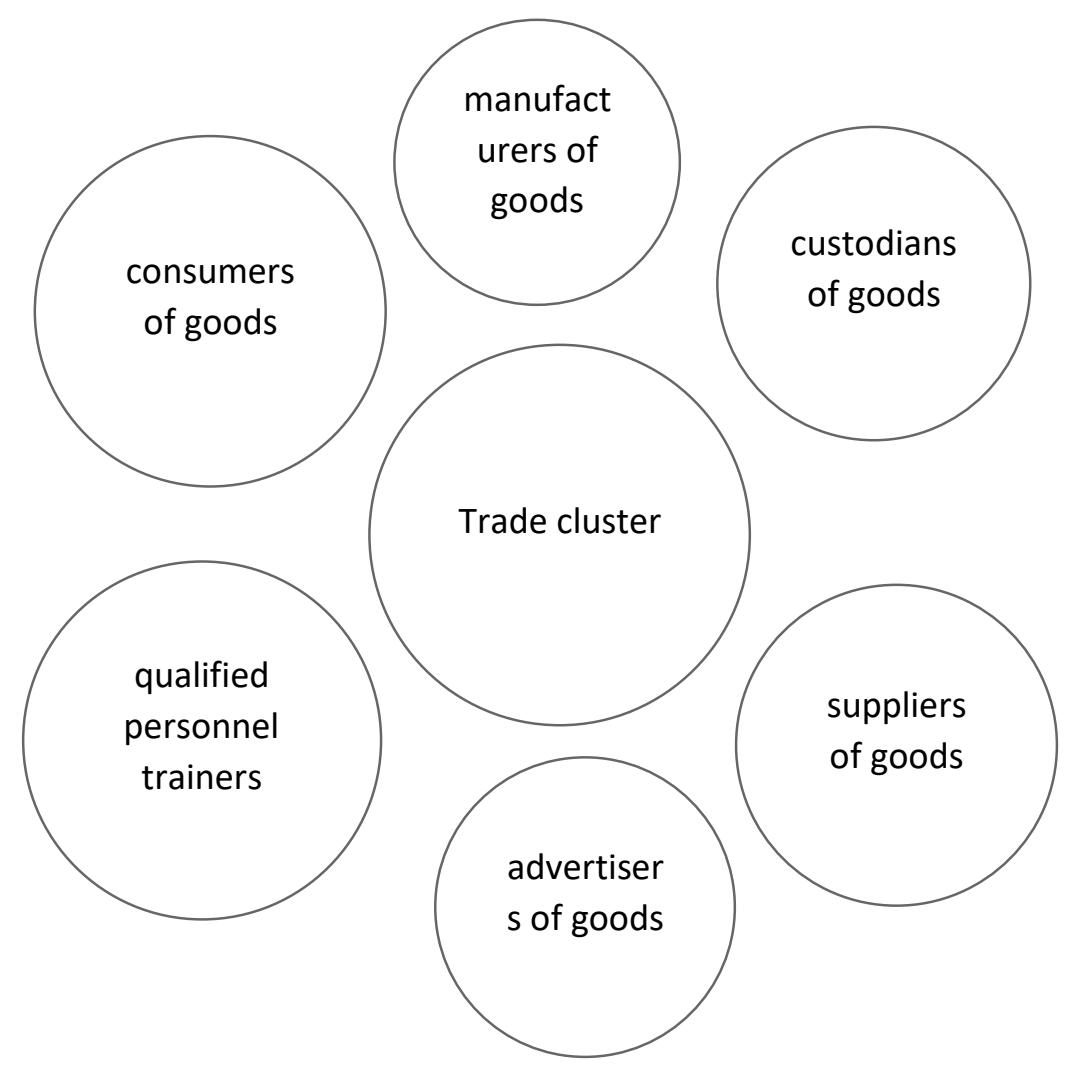

Figure 2. An expanded and modern improved form of trade cluster ${ }^{2}$

The trade cluster system includes the activities of six major elements and integrates the process from the producer to the consumer into a single sales technology chain. This system is one of the important stages in the transition to an innovative economy in trade. The integration of education, production and services in the trade cluster will deepen, creating favorable conditions for the rapid introduction of new innovative technologies into practice.

The main components of the trade cluster are:
1. Manufacturers of goods (enterprises producing imported and domestic goods). Import and domestic producers play an important role in expanding the domestic consumer market of quality goods and their range.

Through the trade cluster, the mechanism of interaction between manufacturing enterprises and trade enterprises will be improved.

2. Storage of goods (manufacturers, wholesalers and logistics companies). The manufactured goods are stored not

${ }^{2}$ Developed by the author 
only in the warehouses of traditional manufacturers and wholesalers, but also in the warehouses of logistics companies operating in a modern form today. Currently, logistics firms provide logistics services such as transportation, receipt, storage, shipment and delivery of goods.

3. Suppliers of goods (manufacturers, wholesalers, intermediaries and logistics firms). Today, goods are delivered to retailers through manufacturers, wholesalers, intermediaries and logistics companies.

4. Advertisers of goods and services (media, websites, dealers, buyers). Currently, retailers advertise their goods and services through the media, websites, dealers and buyers. In particular, trade enterprises, as one of the victims of the pandemic, focused on the strategy of organizing trade via the modern Internet in order to achieve competitiveness.

5. Suppliers of qualified personnel (Higher education institutions and professional colleges). Today, qualified personnel play a key role in increasing the competitiveness and economic efficiency of enterprises operating in all sectors and industries. In this regard, highly educated and qualified sales staff play an important role in the trade cluster. Qualified personnel are trained by universities and professional colleges. Currently, highly educated and qualified personnel for the trade sector are being trained at TSU and SamISI in the field of "Trade".

6. Consumers of goods (buyers). The last link in the trade cluster is the buyers.

\section{CONCLUSION}

The main task of the trade cluster is to strengthen the competitiveness and economic efficiency of trade enterprises through the provision of quality trade services.

As a result of the cluster approach to the provision of trade services, trade enterprises will become more competitive, economic and social relations between the subjects of trade will develop and will lead to the formation of a unified system of trade services. In our opinion, the trade cluster will create the following opportunities to increase the competitiveness of trade enterprises:

First, it shows ways to increase their profits, achieve economic efficiency and increase competitiveness by developing economic and social relations between trade enterprises and consumers of trade services;

Secondly, it will create clear mechanisms for the development of trade services by trade enterprises;

Third, to increase the interest of trade enterprises in the trade cluster and identify opportunities for their sustainable and effective development in the form of an integrated system.

In conclusion, it should be noted that the organization of the cluster is an important system that provides economic and social development not only of enterprises and organizations operating in it, but also of the region.

\section{REFERENCES}

1. Mirziyoev Sh.M. Address of the President of the Republic of Uzbekistan Shavkat 
Mirziyoyev to the Oliy Majlis // People's speech, January 25, 2020.

2. Aslanova D.X., Alimova M.T. Opportunities for the formation of a regional tourism cluster in Samarkand region. Scientific electronic journal "Economy and Innovative Technologies". № 4, July-August, 2016.

3. A.G. Granberg Fundamentals of Regional Economics: Textbook.- M: SU HSE, 2000.

4. Pardaev O.M. Efficiency in product storage enterprises: content, criteria, indicators, factors and ways of their evaluation. Monograph. - T .: "Economy”, 2012.

5. Problems of Trade Economics: A Study Guide. Team of authors. Under the general editorship of MK Pardaev. Study guide. - T .: "Economy-Finance", 2016.

6. Porter M. Competition. - M .: Izdatelskiy dom "Williams", 2011.

7. https://www.stat.uz. Official site of the State Statistics Committee of the Republic of Uzbekistan.

8. https://samstat.uz. Official site of the Samarkand regional department of statistics of the Republic of Uzbekistan.. 